\title{
The foliar change in two species of Melaleuca (Myrtaceae): a morpho- anatomic and ontogenetic approach
}

\author{
V. M. Dörken ${ }^{1} \cdot$ R. F. Parsons ${ }^{2}$
}

\begin{abstract}
Key message In Melaleuca minutifolia mature leaves are linear, in Melaleuca micromera scale-like and peltate. This peltation is caused by swollen basal mesophyll without meristematic fusions. Thus, a novel peltation strategy is described.

Abstract The foliar change of two Australian Melaleuca species (Myrtaceae) was investigated in different ontogenetic stages from cotyledons up to the mature leaf types. In both taxa (M. minutifolia and M. micromera), a strong leaf reduction occurs. While in M. minutifolia the mature leaf type is linear, inverse bifacial and strongly adpressed to the shoot axis, in $M$. micromera it is scale-like, aequifacial, minute and peltate. The mature leaf type of M. micromera is one of the rare examples of peltation among woody species. The ontogenetic studies on the mature peltate leaf type of M. micromera showed that a shield-like leaf base and typical peltate leaf morphology can be formed, not exclusively by meristematic fusions, as is the case for peltate leaves in the classical sense, but instead by strongly swollen mesophyll, particularly in the basal part of the leaf. While most species with peltate leaves are herbaceous perennials from very moist to aquatic habitats and lack reduced leaves, the four Melaleuca species known with the M. micromera type of peltation are from habitats showing either seasonal water stress, soil infertility or both and all show extreme leaf reduction. Given our morpho-anatomical data, it is clear that, as well as the classical type of peltation, a novel, second strategy for achieving peltation needs to be distinguished. The two types are correlated with quite different environmental conditions.
\end{abstract}

Keywords Peltation · Phyllotaxis · Leaf transformation $\cdot$ Scale leaf $\cdot$ Aequifacial $\cdot$ Bifacial

\section{Introduction}

This paper continues a small series dealing with foliar changes and leaf reduction in seed plants (Dörken 2013; Dörken and Parsons 2016, 2017; Dörken et al. 2017). Within several groups of seed plants, a shift in the foliage from juvenile to strongly reduced scale or imbricate mature leaves is observable. For example, several conifers,

Communicated by U. Luettge.

V. M. Dörken

veit.doerken@uni-konstanz.de

R. F. Parsons

r.parsons@latrobe.edu.au

1 Department of Biology, University of Konstanz, M 613, Universitätsstr. 10, 78457 Constance, Germany

2 Department of Ecology, Environment and Evolution, La Trobe University, Bundoora, Melbourne, VIC 3086, Australia e.g., Cupressaceae like Thuja, Thujopsis, Cupressus, Chamaecyparis (Baker and Smith 1910; Coulter and Chamberlain 1928; De Laubenfels 1953; McMillan 1956; Langner 1963; Foster and Gifford 1974; Schütt 2004; Little 2006; Eckenwalder 2009; Dörken 2013) and Podocarpaceae like Dacrydium and Dacrycarpus (Brodribb and Hill 1998; Biffin et al. 2012; Dörken and Parsons 2016) develop needle leaves before shifting to the mature scale or imbricate leaf type later. A comparable shift in the foliage is also observable in some angiosperms, e.g., among Tamaricaceae like Tamarix and Myricaria (Dörken et al. 2017). In the taxa mentioned above the complete leaves become strongly reduced in their overall size. In other taxa, e.g., many species of Acacia (Fabaceae, Angiospermae) (Cambage 1914; Howchin 1930; Pedley 1986) the lamina becomes more and more reduced so that finally only leaf-like phyllodes are developed in mature plants. In other taxa, especially in those where the mature leaves and the shoot axis are fused to each other to form a common 
photosynthetic structure, the changes in the foliage and the shoot morphology and shoot anatomy are much more complex as is the case for, e.g., the phylloclades formed in mature trees of Phyllocladus (Podocarpaceae, Gymnospermae) (Keng 1963, 1974, 1979; Tetzlaf 2005). In mature trees of Casuarina (Casuarinaceae, Angiospermae), the leaves are strongly fused to each other and also to the shoot axis so that finally the shoot axis is completely surrounded by chlorenchymatic leaf-tissue. In Casuarina this fusion is so strong that finally only the leaf-tips still remain free (Dörken and Parsons 2017). Within taxa with such highly modified morphology it is quite difficult to distinguish which is leaf and which is shoot axis tissue.

The evolutionary interpretation, especially of the juvenile foliage in taxa showing strongly reduced or modified leaves when mature, is still a highly controversial topic. In earlier days, such foliar shifts as described above were often related to the "Rekapitulationstheorie" established by Ernst Häckel in 1866 which suggests that ontogeny recapitulates the phylogeny of a particular taxon (Cambage 1914; Howchin 1930; Stebbins 1950; Pedley 1986). While this theory is now often criticized on a number of grounds (Barnes 2014), nevertheless it pre-supposes correctly that there will be changing environmental conditions which underly and drive the change from the ancestral condition to the later one. In the present case, the most important conditions leading to leaf reduction are water deficit (e.g., Thoday 1931; Blum and Arkin 1984; Blum 1996; Bosabalidis and Kofidis 2002; Korner 2003; Parsons 2010; Seidling et al. 2012), low temperatures, in some cases combined with water deficit (e.g., Parsons 2010) and nutrient-poor-soils (e.g., Loveless 1961, 1962; Beadle 1966; Seddon 1974; Hill and Merrifield 1993; Hill 1998; Salleo and Nardini 2000; Düll and Kutzelnigg
2011; Dörken and Jagel 2014; Dörken and Parsons 2016, 2017; Dörken et al. 2017).

In this project, we have chosen two Western Australian Melaleuca species (M. micromera and M. minutifolia, Myrtaceae) which also show a significant shift in their foliage from juvenile to mature individuals. They were chosen because they differ significantly in their mature leaf morphology. Mature plants of $M$. micromera have scale-like to nearly globose leaves while those of $M$. minutifolia have strongly reduced imbricate leaves that are adpressed to the shoot axis. Furthermore, the species were chosen because they differ in their natural distributions.

This study has two major aims. First, it documents the morpho-anatomical changes in the leaves in different ontogenetic stages from seedlings to mature plants, including the leaf morphogenesis of mature leaves. Second, it seeks to understand and explain the structural and developmental changes in the foliage leading to leaf reduction in mature plants.

\section{Materials and methods}

\section{Material}

Melaleuca micromera Schauer is a shrub to $4 \mathrm{~m}$ high which occurs in south-west of Western Australia from the south coast near Albany (34 ${ }^{\circ}$ 'S) up to $100 \mathrm{~km}$ inland usually in sclerophyll forest on infertile lateritic soils (Brophy et al. 2013; Australia's Virtual Herbarium (AVH) 2017). The climate is Mediterranean with wet winters and droughts during summer (Table 1). In contrast, M. minutifolia F. Muell. is a shrub or tree 1-15 $\mathrm{m}$ high found across northern Australia north of $22^{\circ} 9^{\prime} \mathrm{S}$ (AVH 2017). It can dominate scrubs and
Table 1 Ranges of long-term mean values for some rainfall and temperature parameters within the distributions of Melaleuca micromera and $M$. minutifolia

\begin{tabular}{lll}
\hline Climatic parameter & Species & \\
\cline { 2 - 3 } & M. micromera & Minutifolia \\
\hline General & & Subtropical \\
Climatic type & Mediterranean & $13^{\circ} 7^{\prime}-22^{\circ} 1^{\prime}$ \\
Latitude $\left({ }^{\circ} \mathrm{S}\right)$ & $34^{\circ} 0^{\prime}-34^{\circ} 7^{\prime}$ & \\
Rainfall & & $344-1089$ \\
Mean annual $(\mathrm{mm})$ & $349-584$ & $279-826$ \\
Mean summer $(\mathrm{mm})$ & $46-68$ & $2-71$ \\
Mean winter $(\mathrm{mm})$ & $153-331$ & $27.3-35.4$ \\
Temperature & & $15.0-21.8$ \\
Mean annual maximum $\left({ }^{\circ} \mathrm{C}\right)$ & $19.8-20.7$ & November (spring) \\
Mean annual minimum $\left({ }^{\circ} \mathrm{C}\right)$ & $8.6-10.1$ & $31.8-39.8$ \\
Warmest month & January (summer) & $19.4-25.7$ \\
Mean maximum warmest month $\left({ }^{\circ} \mathrm{C}\right)$ & $24.6-28.9$ & July (winter) \\
Mean minimum warmest month $\left({ }^{\circ} \mathrm{C}\right)$ & $12.7-14.2$ & July (winter) \\
Coolest month & & \\
\hline
\end{tabular}

Data from Atlas of Living Australia, seen on 9 May (2017) 
low woodlands or can occur in the understorey of Eucalyptus and Corymbia woodlands (Sharp and Bowman 2004). The soils range from elevated sandy or rocky soils on granite or limestone hills (Brophy et al. 2013; FloraBase 2017) where droughts will certainly occur, to low-lying sites which become seasonally inundated (Sharp and Bowman 2004). The climate is subtropical with a strong summer rainfall incidence (Table 1).

The great difference between wet winters/dry summers and the reverse makes it very difficult to assess which of the two species occurs in the most xeric habitats. While $M$. micromera is clearly found in low soil nutrient conditions, it seems that $M$. minutifolia probably occurs over a wide range of nutrient levels. Such habitat characteristics mean that, in this case, it is often not possible to assess whether particular morphological features are related to the water factor (xeromorphy), the nutrient factor (scleromorphy) or both.

Seeds of M. micromera and M. minutifolia were obtained from Nindethana Seed Service, Post Office Box 2121, Albany, Western Australia, 6331. They were germinated and grown in a temperate glasshouse with long day conditions in the Botanic Garden Konstanz, Germany. Seeds were sown in a mixture of compost and vermiculite (5:1). The glasshouse temperature ranged from $25{ }^{\circ} \mathrm{C}$ (day) to $15^{\circ} \mathrm{C}$ (night). Material from adult individuals was also collected in the Botanic Garden Konstanz where the plants are cultivated in a temperate house. Voucher specimens are lodged at the FRPHerbarium of the Palmengarten Frankfurt a. M. (Germany).

\section{Methods}

Freshly collected material was photographed and then fixed in FAA $[100 \mathrm{ml}$ FAA $=90 \mathrm{ml}$ ethanol $(70 \%)+5 \mathrm{ml}$ acetic acid $96 \%+5 \mathrm{ml}$ formaldehyde solution $37 \%$ ] before being stored in $70 \%$ ethanol. The leaf anatomy was studied from serial sections using the classical paraffin technique and subsequent astra-blue/safranin staining (Gerlach 1984). Macrophotography was accomplished using a digital camera (Canon PowerShot IS2) and microphotography with a digital microscope (Keyence VHX 500F) equipped with a high-precision $\mathrm{VH}$ mounting stand with $\mathrm{X}-\mathrm{Y}$ stage and bright-field illumination (Keyence VH-S5).

\section{Special terms}

Three major terms describing leaf structure depending on abaxial-adaxial correlation are frequently used: bi-, aequi- and unifacial (e.g., Jurzitza 1987; Bresinsky et al. 2008; Wagenitz 2008; Weiler and Nover 2008; Kück and Wolf 2009; Taiz et al. 2014). In English literature, the terms bi- and unifacial are common (e.g., Beck 2010; Rudall 2007), while aequifacial is rare and is usually spelt equifacial (Taiz et al. 2014). In German literature, all three terms are frequently used.

\section{Bifacial leaves}

Leaves with two clearly distinguishable surfaces, whose formation depends on their exposure to light. The upper lightexposed surface corresponds to the morphologically adaxial side, with strongly thickened epidermal cells, a thick cuticle and no or only few stomata. The lower surface corresponds to the morphologically abaxial side, with weakly thickened epidermal cells, a thin cuticle and a high number of stomata. The mesophyll is dimorphic with palisade parenchyma towards the adaxial and spongy parenchyma spaces towards the abaxial surface. Both leaf surfaces come into contact at the leaf margin. The vascular bundles are placed in the same plane, with xylem located towards the adaxial and phloem towards the abaxial side. If the morphologically abaxial surface is the lightexposed one, then the morpho-anatomical structure becomes reversed, leading to the formation of inverse bifacial leaves.

\section{Aequifacial (= isobilateral) leaves}

Leaves which are mostly vertically orientated so that all parts are light-exposed, leading to the formation of the same morpho-anatomical features on both leaf surfaces. At the leaf margin both leaf surfaces come into contact. Stomata are developed on both sides in the same quantity. Strongly thickened epidermal cells and thick cuticle are developed all over the surface and palisade parenchyma is developed on both sides. The vascular bundles are in the same plane. Which part of the leaf corresponds to the morphologically ad- or abaxial side can be recognized by the orientation of xylem (adaxial) and phloem (abaxial).

\section{Unifacial leaves}

Leaves with mostly tube-like or roundish shape. They are characterized by strong reductions, mostly of the adaxial side, leading to the lack of two clearly distinguishable surfaces and a leaf margin. The vascular bundles are diffuse or mostly ring-like in arrangement. If the morphologically adaxial side is reduced, xylem becomes orientated towards the center of the leaf and phloem becomes peripheral.

\section{Results}

\section{Melaleuca minutifolia}

\section{Cotyledons}

A well developed hypocotyl occurs (Fig. 1a) below the flattened and ovate cotyledons which are about 5-7 mm long and 2.5-3 mm wide (Fig. 1a). There is no distinct petiole developed (Fig. 1a). The lamina is in a plagiotropic 

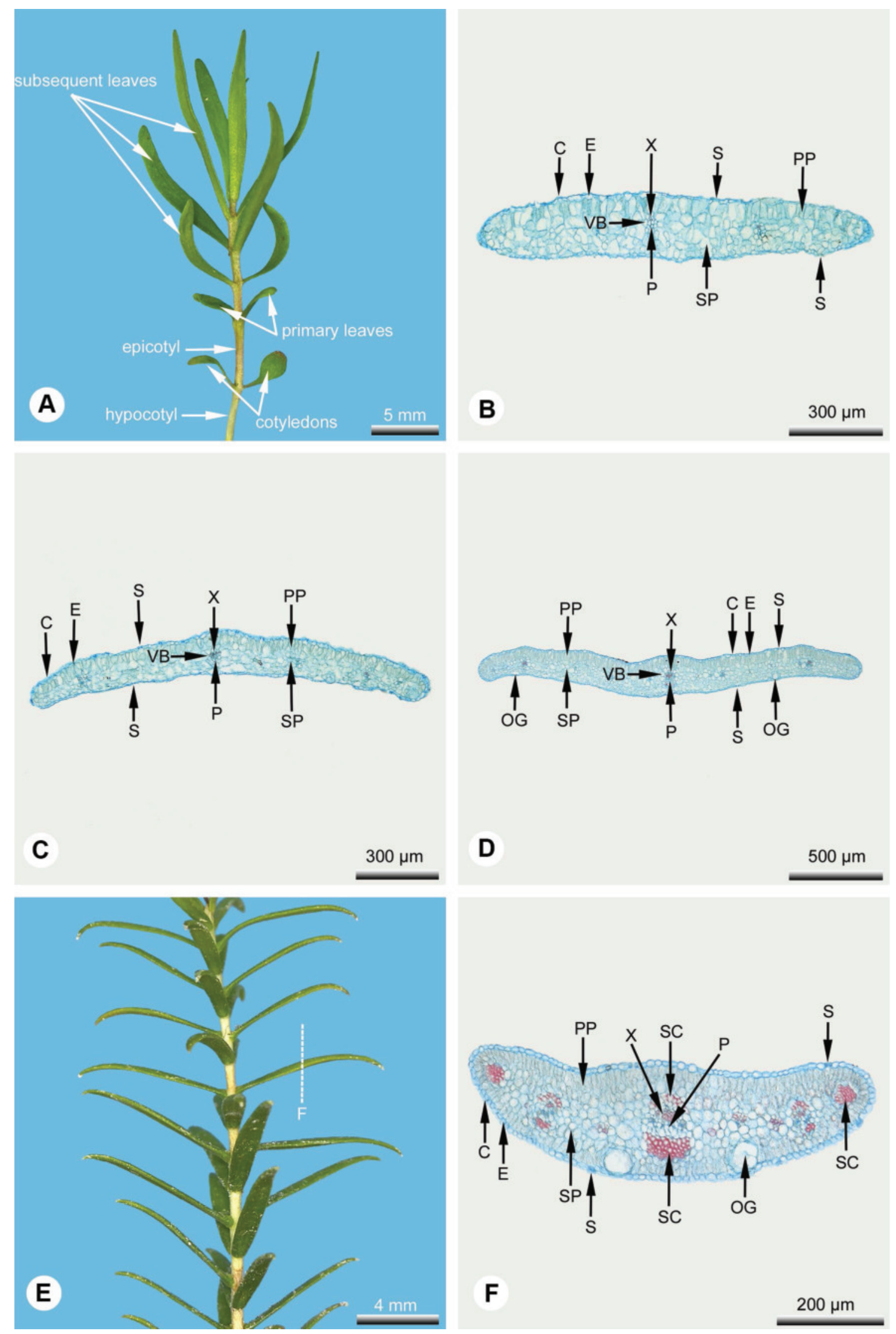
4 Fig. 1 Melaleuca minutifolia, leaves in different ontogenetic stages I; a juvenile leaves on a seedling; $\mathbf{b}$ cotyledon (cross section); c primary leaf (cross section); d first subsequent juvenile leaf (cross section); $\mathbf{e}$, $\mathbf{f}$ juvenile needle leaves; $\mathbf{f}$ cross section as marked in e. ( $C$ cuticle, $E$ epidermis, $O G$ oil gland, $P P$ palisade parenchyma, $P$ phloem, $S$ stoma, $S C$ sclerenchyma, $S P$ spongy parenchyma, $V B$ vascular bundle, $X$ xylem)

orientation so that the morphologically adaxial side is light-exposed and the morphologically abaxial side shaded. The cotyledons are amphistomatic, most stomata are, however, developed abaxially. The stomata are only slightly sunken in the epidermis or more or less in the same plane. The epidermal cells of both sides are similar in size and shape and have a thin cuticle. The cotyledons are bifacial with a dimorphic mesophyll showing a palisade parenchyma placed towards the light-exposed adaxial and a spongy parenchyma placed towards the shaded abaxial side. The palisade parenchyma consists of 1-3 layers of cells. The spongy parenchyma shows irregularly shaped cells. Oil glands and sclerenchyma are absent. There is one collateral vascular bundle strand supplying the cotyledons. The midvein branches several times, ends just before the cotyledon tip and lacks a bundle sheath (Fig. 1b).

\section{Primary leaves}

The epicotyl is well developed and about 5-10 $\mathrm{mm}$ long (Fig. 1a). The two opposite primary leaves are $4-5 \mathrm{~mm}$ long and 1.5-2 mm wide (Fig. 1a). In all other morphoanatomical features they are similar to the cotyledons (Fig. 1a, b).

\section{First subsequent juvenile leaves}

The internodes between the first decussate subsequent juvenile leaves are about $2-3 \mathrm{~mm}$ long. The leaves are about $8-10 \mathrm{~mm}$ long and $2-2.5 \mathrm{~mm}$ wide. Towards the abaxial side, small glands, containing a fragrant essential oil, are developed in the mesophyll (Fig. 1d). In all other morphoanatomical features they correspond to the situation in cotyledons (Fig. 1a, b).

\section{Juvenile needle leaves}

The juvenile needle leaves are decussate, about 5-12 mm long and 1-1.5 mm wide (Fig. 1e). The cells of the epidermal layer are strongly thickened. Stomata are not deeply sunken in the epidermal layer and the respiratory chamber is small. The vascular bundle strands are surrounded by a distinct sclerenchyma consisting of strongly thickened, lignified cells. Below the vascular bundle the sclerenchyma has its maximum thickness. Towards the leaf margin clusters of sclerenchymatic cells without an association to a vascular bundle are also developed. At the abaxial side, directly below the epidermal layer, there are several huge oil glands, filled with a fragrant essential oil (Fig. 1f). In all other features the juvenile needle leaves are quite similar to the first subsequent juvenile leaves (Fig. 1a, d).

\section{Juvenile transitional leaves}

The juvenile transitional leaves that take over from the juvenile plagiotropic leaves (cotyledons, primary leaves, first subsequent leaves, juvenile needle leaves) and lead to the imbricate leaves are decussate, about 4-11 mm long and 1-1.2 mm wide and in an erect position (Fig. 2a) so that both leaf sides are light-exposed. These leaves are quite similar to the juvenile needle leaves, but differ from them in their aequifacial structure and stomata that are distributed on both leaf sides in more or less the same density (Fig. 2b).

\section{Juvenile imbricate leaves}

The juvenile imbricate leaves are strongly adpressed to the shoot axis. Thus, the abaxial side is light-exposed, the adaxial side shaded. The leaves are decussate, 7-10 $\mathrm{mm}$ long and 0.7-1 mm wide (Fig. 2c). In most anatomical features the juvenile imbricate leaf type corresponds to the juvenile transitional leaves (Fig. 1e, f), but differ from them by showing a bifacial structure, with palisade parenchyma located towards the abaxial and spongy parenchyma towards the adaxial leaf side (Fig. 2d).

\section{Mature imbricate leaves}

Mature imbricate leaves are decussate, about 2-5 mm long and about $0.4-1 \mathrm{~mm}$ wide (Fig. 2e). They differ from the juvenile imbricate leaves (Fig. 2c, d) in the distribution of stomata, the leaves being nearly completely epistomatic (Fig. 2e, f).

The ontogeny of mature leaves is comparatively simple (Fig. 3b). They are arranged in decussate pairs (Fig. 3a). In the first ontogenetic steps, the length of the lamina increases strongly, and its base is only slightly narrowed. The aequifacial petiole is strongly reduced. Even in the earliest ontogenetic stages, the differentiation of the mesophyll into palisade and spongy parenchyma takes place. In subsequent steps, the width of the lamina expands, but significantly less than the expansion in length. The mesophyll becomes only slightly thickened. Throughout their ontogeny, mature leaves remain adpressed to the shoot axis and the leaf base remains sessile. This development leads finally to the formation of imbricate, flattened needle leaves that are strongly adpressed to the shoot axis. 

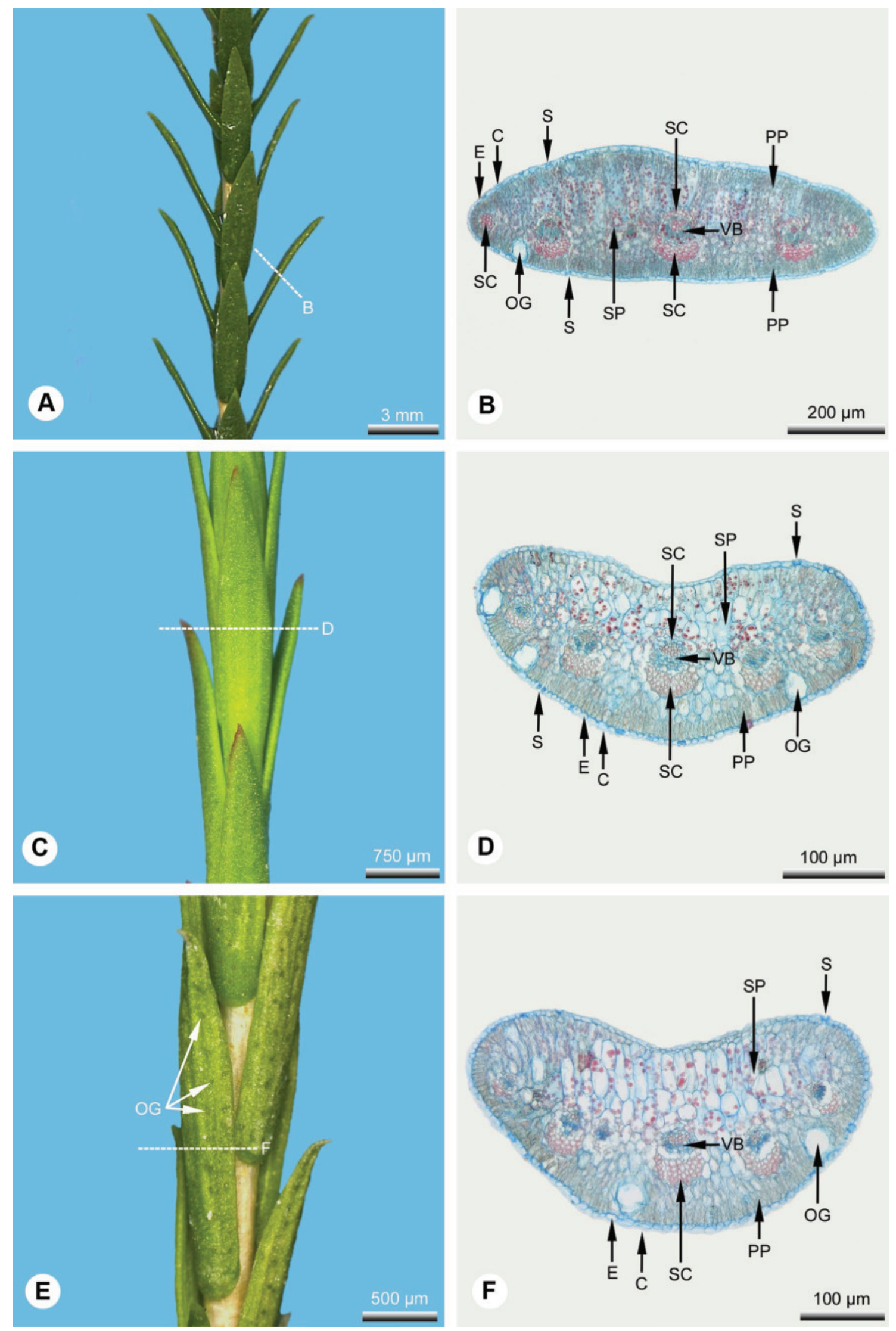
4Fig. 2 Melaleuca minutifolia, leaves in different ontogenetic stages II; $\mathbf{a}, \mathbf{b}$ juvenile transitional leaves; $\mathbf{b}$ cross section as marked in $\mathbf{a} ; \mathbf{c}, \mathbf{d}$ young imbricate leaves; $\mathbf{d}$ cross section as marked in $\mathbf{c} ; \mathbf{e}, \mathbf{f}$ mature imbricate leaves; $\mathbf{f}$ cross section as marked in e. $(C$ cuticle, $E$ epidermis, $O G$ oil gland, $P P$ palisade parenchyma, $P$ phloem, $S$ stoma, $S C$ sclerenchyma, $S P$ spongy parenchyma, $V B$ vascular bundle, $X$ xylem)

\section{Melaleuca micromera}

\section{Cotyledons}

The seedlings have a well developed hypocotyl that lacks trichomes. The two cotyledons are flattened and obovate, about 3-5 mm long and 1.5-2 mm wide. They are in a plagiotropic orientation (Fig. 4a). The morphologically adaxial side is light-exposed, the morphologically abaxial side shaded. The cotyledons are amphistomatic; however, the majority of stomata are located abaxially. They are only slightly sunken in the epidermis or in the same plane with the epidermal layer. The epidermal cells of both sides are similar in size and shape. Only those of the lateral margins are about double the size compared to those of the ad- and abaxial sides (Fig. 4b). The epidermis is covered with a thin cuticle. The cotyledons have a bifacial mesophyll structure with palisade parenchyma towards the adaxial and spongy parenchyma towards the abaxial side. The palisade parenchyma consists of 1-3 layers of cells. The cells of the spongy parenchyma are isodiametric. Oil glands or sclerenchyma are absent. The cotyledons are supplied with one collateral vascular bundle strand that branches several times. The midvein ends shortly below the cotyledon tip. Within the mesophyll, the vascular bundles are placed in the same plane. There is no distinct bundle sheath (Fig. 4b).

\section{Primary leaves}

The epicotyl is strongly reduced and about $0.5-1 \mathrm{~mm}$ long and glabrous (Fig. 4a). The two primary leaves are opposite, 4-6 mm long and 1.5-2 mm wide (Fig. 4c). In all other morpho-anatomical features they are similar to cotyledons (Fig. 4a, b).

\section{First subsequent juvenile leaves}

The internodes between the first subsequent leaves are about 3-4 mm long. The shoot axis is glabrous (Fig. 4a). The decussate leaves are about 5-8 $\mathrm{mm}$ long and 2-2.5 mm wide (Fig. 4d). In all other morpho-anatomical features they are similar to cotyledons (Fig. 4a, b).

\section{Juvenile needle leaves}

The glabrous internodes of young shoots are about $0.5-1.3 \mathrm{~mm}$ long. The juvenile needle leaves are in a spiral alternating orientation, about 4-8 mm long and 0.6-1.2 mm wide (Fig. 4e). They are quite similar to the first subsequent juvenile leaves (Fig. 4a, d), but differ from them by the presence of huge oil glands that are located in the mesophyll towards both sides of the leaf and by vascular bundles that are flanked by clusters of sclerenchymatic cells (Fig. 4f).
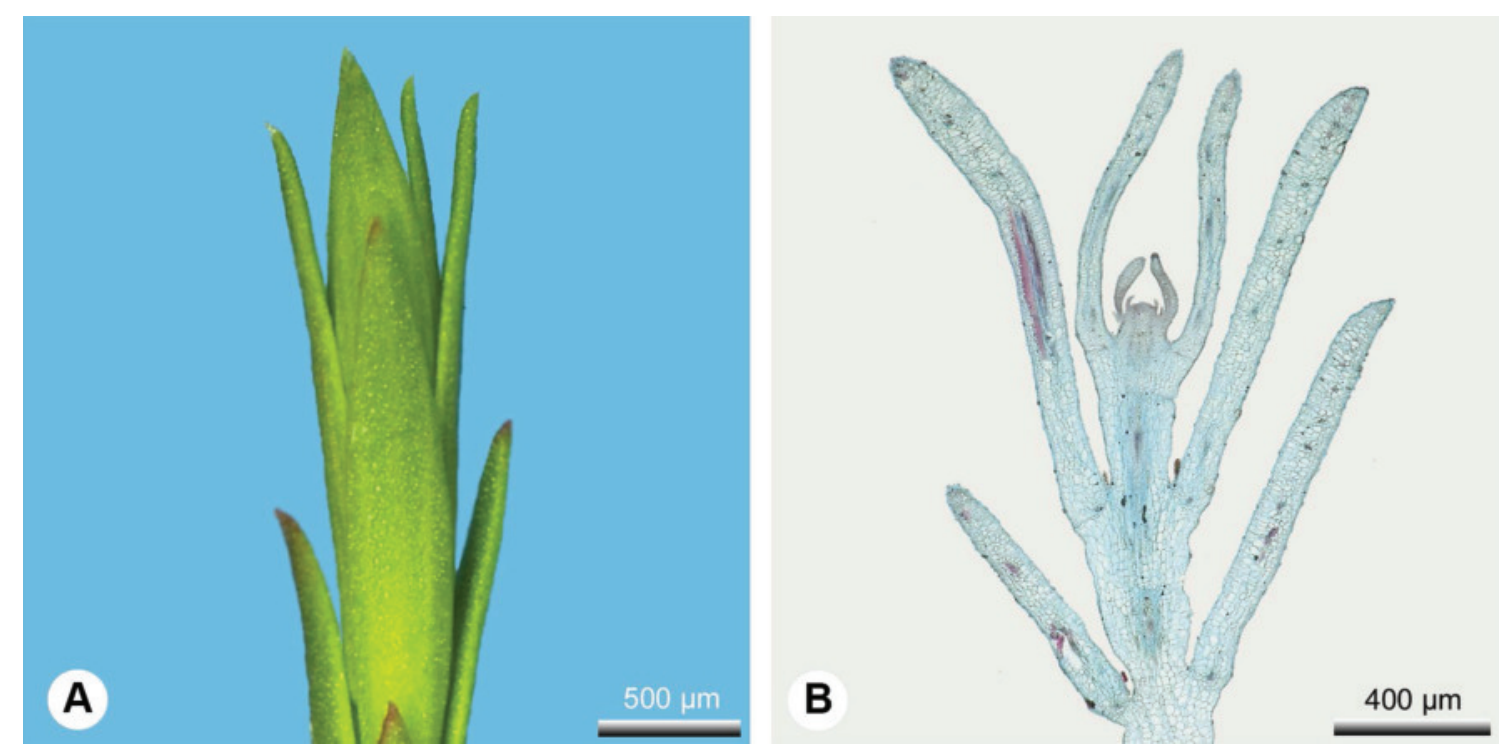

Fig. 3 Melaleuca minutifolia, morphogenesis of mature leaves; a detail of a shoot apex with inserted young leaves in different ontogenetic stages; $\mathbf{b}$ cross section of the shoot showing leaves in different ontogenetic stages 

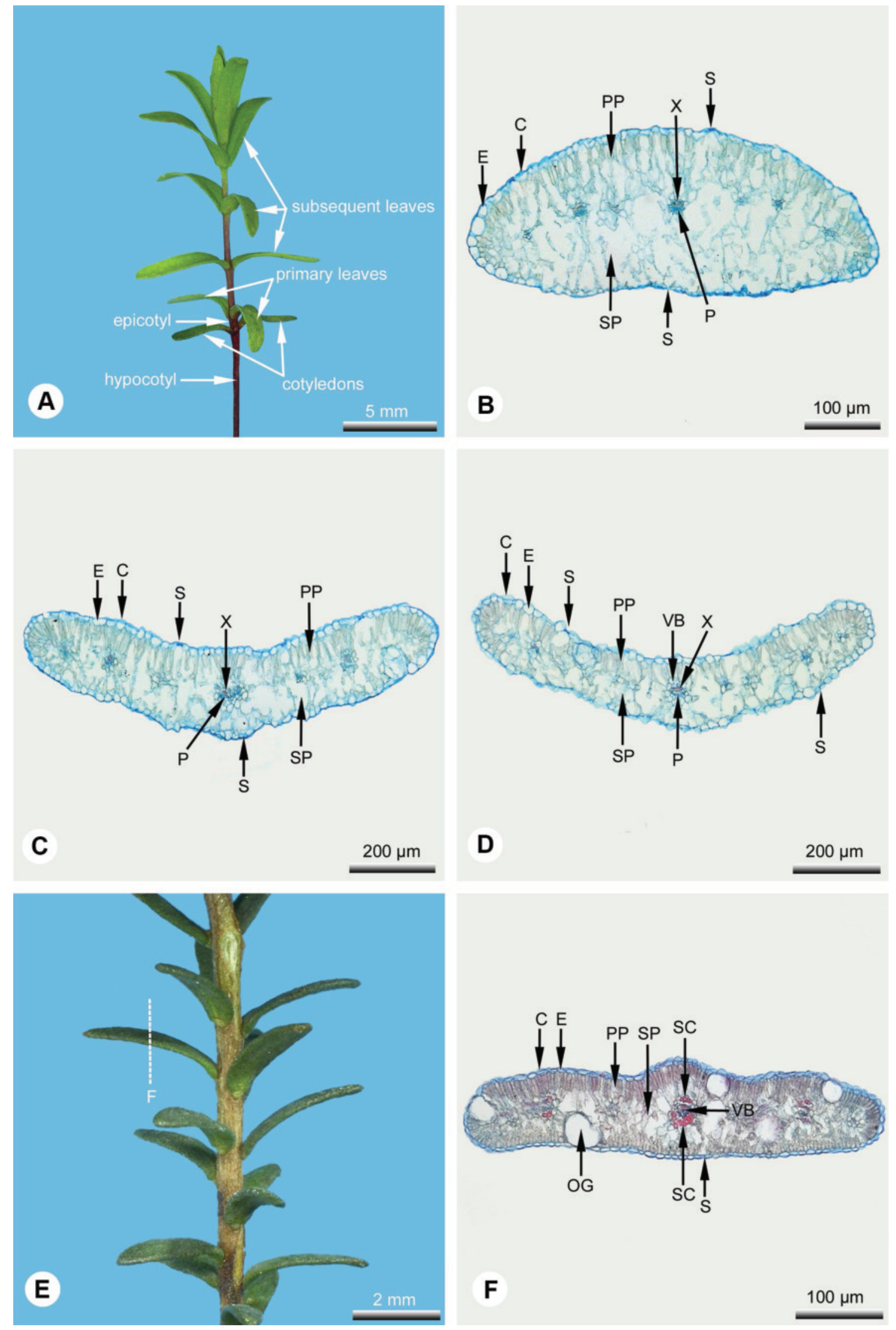
4Fig. 4 Melaleuca micromera, leaves in different ontogenetic stages I; a juvenile leaves on a seedling; b cotyledon (cross section); c primary leaf (cross section); $\mathbf{d}$ first subsequent juvenile leaf (cross section); $\mathbf{e}$, $\mathbf{f}$ juvenile needle leaves; $\mathbf{f}$ cross section as marked in e. ( $C$ cuticle, $E$ epidermis, $O G$ oil gland, $P P$ palisade parenchyma, $P$ phloem, $S$ stoma, $S C$ sclerenchyma, $S P$ spongy parenchyma, $V B$ vascular bundle, $X$ xylem)

\section{Juvenile transitional leaves}

The internodes are about $0.5-1.2 \mathrm{~mm}$ long. When the transitional leaves develop, the shoot axis becomes strongly pubescent and covered with light brownish trichomes. The transitional leaves are arranged in whorls of three, $1.0-1.5 \mathrm{~mm}$ long and $0.8-1.0 \mathrm{~mm}$ wide. They are in an upright position so that the adaxial leaf side is more or less orientated towards the shoot axis so that the abaxial leaf side becomes light-exposed and the palisade parenchyma is no longer only developed towards the adaxial side, but also towards the abaxial side so that the leaves become aequifacial (Fig. 5a). The leaves are amphistomatic, with stomata at the same density on both leaf sides. The epidermis in lightexposed parts is covered with a thick cuticle. This is thinner in the shaded parts. The mesophyll is dimorphic with palisade parenchyma developed towards the light-exposed parts of the leaf and spongy parenchyma towards the shaded parts. The palisade parenchyma consists of 1-3 layers of cells. The spongy parenchyma consists of isodiametric cells and large intercellular spaces. The vascular bundles, which are arranged in more or less the same plane, are surrounded by a sclerenchyma of strongly lignified cells. A special bundle sheath is absent. Within the mesophyll, several oil glands, filled with a fragrant essential oil, are developed (Fig. 5b).

\section{Mature scale leaves}

In mature individuals, the distal parts of the shoot axis are strongly pubescent (Fig. 5c). Mature scale leaves are arranged in alternating whorls of three. The minute leaves are $0.5-1.2 \mathrm{~mm}$ long and $0.5-1 \mathrm{~mm}$ wide. The mature leaf type is also aequifacial, similar to the juvenile transitional leaves, but even more reduced and more strongly swollen (Fig. 5c). The vascular bundles are arranged in more or less the same plane. In the shaded parts, the leaf cuticle is quite thin, in the light exposed parts significantly thicker. The leaves are epistomatic. The palisade parenchyma is developed towards all light exposed parts of the leaf (Fig. 5d-f). The mature scale leaf is dominated by several large oil glands placed towards the abaxial side, directly below the epidermal layer or 1-2 cell layers below. The vascular bundle is flanked by sclerenchyma (Fig. 5f).

The mature leaves of $M$. micromera show a highly complex ontogeny (Figs. 6, 7). They are developed in alternating whorls of three. The petiole of the leaf is strongly reduced
(Fig. 6b). The young lamina is strongly incurved so that the abaxial leaf surface is convex and orientated towards the shoot apex. The adaxial leaf surface is strongly concave (Figs. 6c-e, 7b-k). In early ontogenetic stages, the base of the lamina is abruptly narrowed (Figs. $6 c-g, 7 b-e)$. The insertion point of the leaf at the shoot axis is quite minute (Figs. 6c-g, 7b-k). In subsequent ontogenetic steps, the abaxial leaf surface becomes strongly swollen (Figs. 6c-f, $7 \mathrm{f}-\mathrm{k}$ ) which leads to the formation of a distinct basal spurlike bulge (Figs. $6 \mathrm{c}-\mathrm{f}, 7 \mathrm{f}-\mathrm{k}$ ). Due to this, the insertion point of the leaf becomes surrounded by the strongly developing tissues of the leaf base. Thus, the insertion point gets located more and more in a central position of the leaf base (Figs. 6g, 7f-h). In a subsequent ontogenetic step, the adaxial leaf surface also becomes swollen (Fig. 6g-k, 7i-k). The lamina is still slightly incurved and the adaxial leaf surface is still slightly convex and developed towards the shoot axis. At this stage, when the adaxial leaf surface starts to swell, the differentiation of the mesophyll into palisade and spongy parenchyma begins (Fig. 6g). In further ontogenetic steps, the leaf margin, thin until now, becomes thickened. Finally the leaf surfaces of both sides become even more thickened. The basal part of the adaxial leaf surface finally forms a bulge which is comparable to the basal one developed earlier at the abaxial leaf surface (Fig. 6g-k). Due to the continuous swelling of the mesophyll, particularly in the lower one-third of the leaf, a strongly enlarged and shield-like flattened base is formed (Figs. 6k, 7k). Due to this strong basal swelling of the leaf tissues and a lack of space at the shoot axis, the leaf base finally becomes strongly adpressed to the shoot axis. The marked expansion of the leaf base in all directions (Figs. 6g-k, 7i-k) has no influence on the size and shape of the insertion point of the leaf at the shoot axis (Figs. 6k, 7k). Due to the strongly swollen leaf base, the insertion point of the leaf is finally located in the center of a distinct shieldlike, flattened leaf base. Thus, the fully developed mature leaf finally has truly "peltate" morphology (Figs. 6k, 7i-k). Also in mature leaves the petiole has an aequifacial structure.

\section{Discussion}

\section{The shift from juvenile to mature leaves}

Within both investigated Melaleuca species, a significant change in the foliage from juvenile to mature leaves occurs which affects not only the overall leaf size and shape, but also the leaf anatomy and ontogeny, and in M. micromera also the phyllotaxis. The juvenile leaf-types developed in both taxa are quite similar and hardly distinguishable from each other. They are decussate, foliar and linear with a bifacial and amphistomatic structure. The mature leaves of both taxa are strongly reduced in size and characterized by 

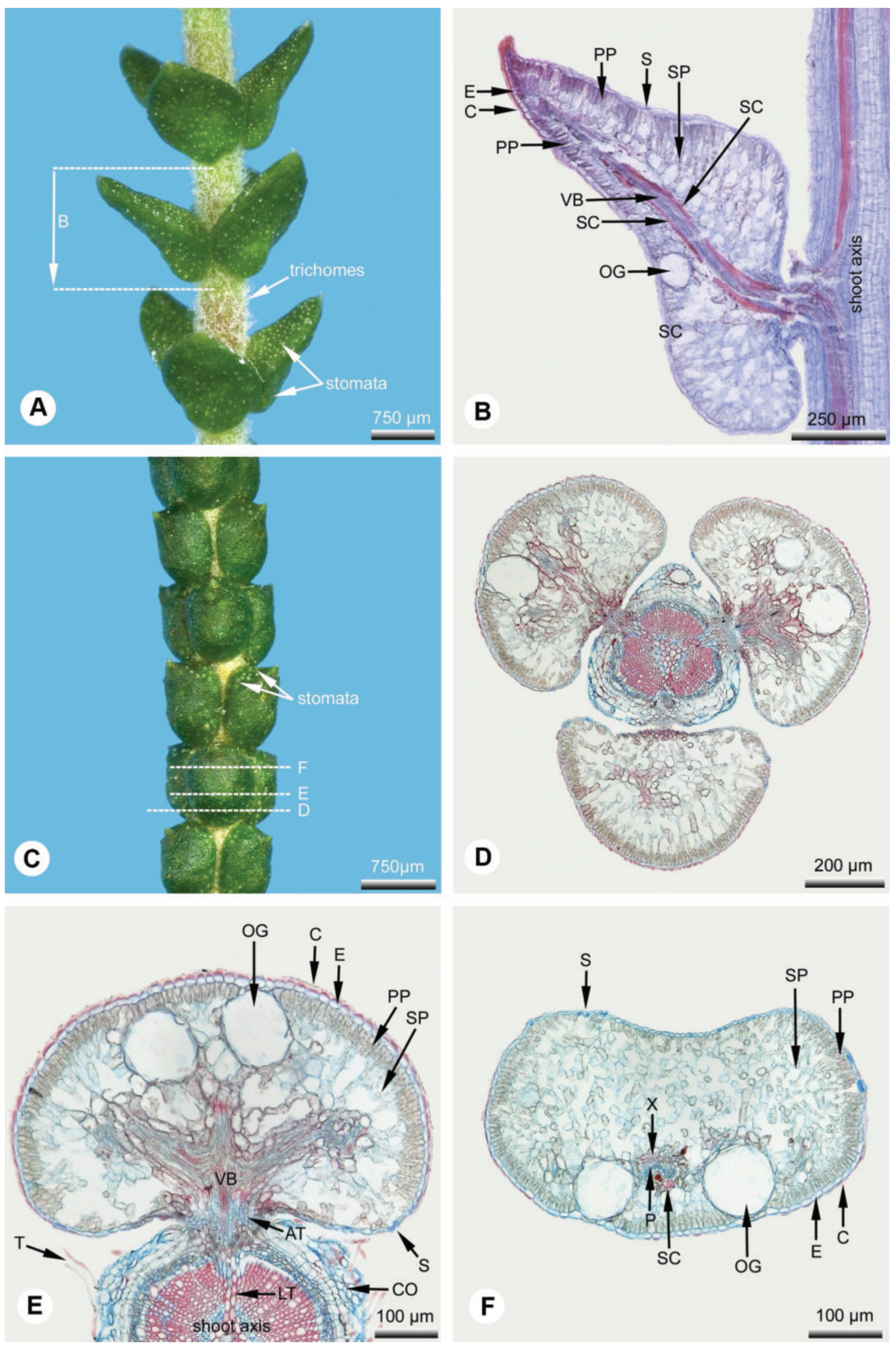
4Fig. 5 Melaleuca micromera, leaves in different ontogenetic stages II; a, b juvenile transitional leaves; $\mathbf{b}$ longitudinal section as marked in $\mathbf{a} ; \mathbf{c}-\mathbf{f}$ mature scale leaves; $\mathbf{c}$ shoot axis and inserted mature scale leaves; $\mathbf{d}$ cross section of a shoot axis and inserted mature scale leaves as marked in c; $\mathbf{e}$ basal part of a mature scale leaf (cross section as marked in $\mathbf{c}$ ); $\mathbf{f}$ distal part of a mature scale leaf (cross section as marked in c). ( $A T$ abscission tissue, $C$ cuticle, $C O$ cortex of shoot axis, $E$ epidermis, $L T$ leaf trace, $O G$ oil gland, $P P$ palisade parenchyma, $P$ phloem, $S$ stoma, $S C$ sclerenchyma, $S P$ spongy parenchyma, $T$ trichomes, $V B$ vascular bundle, $X$ xylem)

distinctly developed clusters of sclerenchyma that are mostly associated with a vascular bundle strand. Despite the morpho-anatomical similarities of juvenile leaves, the mature leaf types of the two taxa differ significantly in their phyllotaxis, leaf shape and ontogeny. In M. minutifolia the phyllotaxis is decussate throughout its whole lifespan (Figs. 1, 2). In M. micromera the cotyledons, primary and subsequent leaves are also decussate (Fig. 4a), while the young needle leaves are in a spiral alternating position (Fig. 4e) leading to the whorled phyllotaxis of mature leaves (Fig. 5c). Already the young transitional scale leaves (Fig. 5a) are arranged in whorls of three.

Apart from the phyllotaxis the mature leaves of both taxa differ strongly in their morphology with $M$. micromera having very thick subcircular, aequifacial, scale leaves while $M$. minutifolia has inverse bifacial, imbricate leaves. For mature leaves the earliest ontogenetic stages of the two species do not differ from each other (Figs. 3, 6). Both taxa develop bifacial leaves which are strongly incurved, with an adaxial surface located towards the apex. The ontogeny of mature leaves in M. minutifolia is simple compared to the complex situation of M. micromera (Figs. 6, 7). In M. minutifolia, mature leaves remain more or less orientated towards the shoot axis and the lamina remains as a flat inverse bifacial structure throughout their complete morphogenesis (Fig. 3). Mature leaves of M. micromera, however, are characterized by strongly swollen leaf tissues, particular in the basal parts. Due to the formation of a strongly swollen, shield-like, flat leaf base the minute insertion point of the leaf at the shoot axis is finally completely surrounded by basal leaf tissues. Thus, at maturity the insertion point is in a central position near the leaf base. This leads finally to the peltate morphology of mature leaves (Figs. 6, 7), but without a shield-like flat distal lamina.

Peltate leaves are quite common among angiospermous taxa, particular among perennial herbs and can be found in about 40 families of all major angiospermous clades (e.g., Troll 1932; Ebel 1998; Gleissberg et al. 2005). Also within the Myrtaceae, the family to which our investigated Melaleuca belongs, Ebel (1998) records peltate leaves for some Eucalyptus taxa but not for Melaleuca or any other genus. Peltate leaves can be roughly divided into two major morphological groups, epipeltate and hypopeltate (Franck
1976; Fukushima and Hasebe 2014). In the epipeltate type, the most common one, the upper surface of the lamina is represented by the morphologically adaxial side of the leaf and, in early developmental stages the laminar margins are fused to each other in basal parts above the petiole, forming a meristematic cross zone (Troll 1932; Franck 1976). The hypopeltate type is quite rare and mostly occurs in special types of stamens (Troll 1932; Weberling 1981). In contrast to epipeltate leaves, the upper surface of the lamina is morphologically the abaxial side of the leaf. It should be noted that peltate leaf development including its molecular genetics is currently an active and productive research field (e.g., Gleissberg et al. 2005; Fukushima and Hasebe 2014).

The ontogeny of peltate leaves developed in $M$. micromeria differs strongly from that of a classical peltate leaf as developed, e.g., in Tropaeolum majus L. (Tropaeolaceae, Angiospermae). Here the marginal meristems of the lamina fuse to form a meristematic cross zone above the petiole. Due to this "meristematic bridge" a closed marginal meristematic ring is formed which finally produces new lamina surface in all directions and leads to a central position of the petiole mostly at the abaxial leaf surface of the lamina (Troll 1932; Franck 1976; Natho et al. 1990; Gleissberg et al. 2005; Throm 2007; Bresinsky et al. 2008; Leins and Erbar 2008, 2010; Fukushima and Hasebe 2014). In contrast, in $M$. micromera, due to the continuous swelling of the lamina (especially in the basal parts) and the lack of a meristematic cross zone, the developmental processes leading to the peltate leaves are very different. However, in the earliest ontogenetic stages both leaf types are typical bifacial structures before they turn to different developmental pathways (compare, e.g., Hagemann and Gleissberg 1996). The peltate leaves of $M$. micromera differ also from classical peltate leaves by the shape and structure of the lamina. The latter have a shield-like flattened structure while in $M$. micromera only the leaf base is shield-like and flat. Furthermore, classical peltate leaves have an unifacial petiole (Franck 1976) with a radial arrangement of vascular bundles (Troll 1932). In M. micromera the petiole has an aequifacial structure, with xylem facing towards the adaxial side as is common for typical bifacial leaves.

To summarize, our results show that a shield-like leaf base and typical peltate leaf morphology can be produced not by meristematic fusions, but by strongly swollen mesophyll in the basal part of the leaf. This occurs in a context of leaf size reduction which is not the case for classical peltation. Thus, it is necessary to recognize two quite different types of peltation.

At least three other Melaleuca species, M. foliolosa A. Cunn. ex Benth., M. tamariscina Hook. and M. thyoides Turcz. have minute peltate leaves of very similar morphology to M. micromera (Bentham 1866; Brophy et al. 2013) as does the shrub Ozothamnus scutelliformis Hook f. 

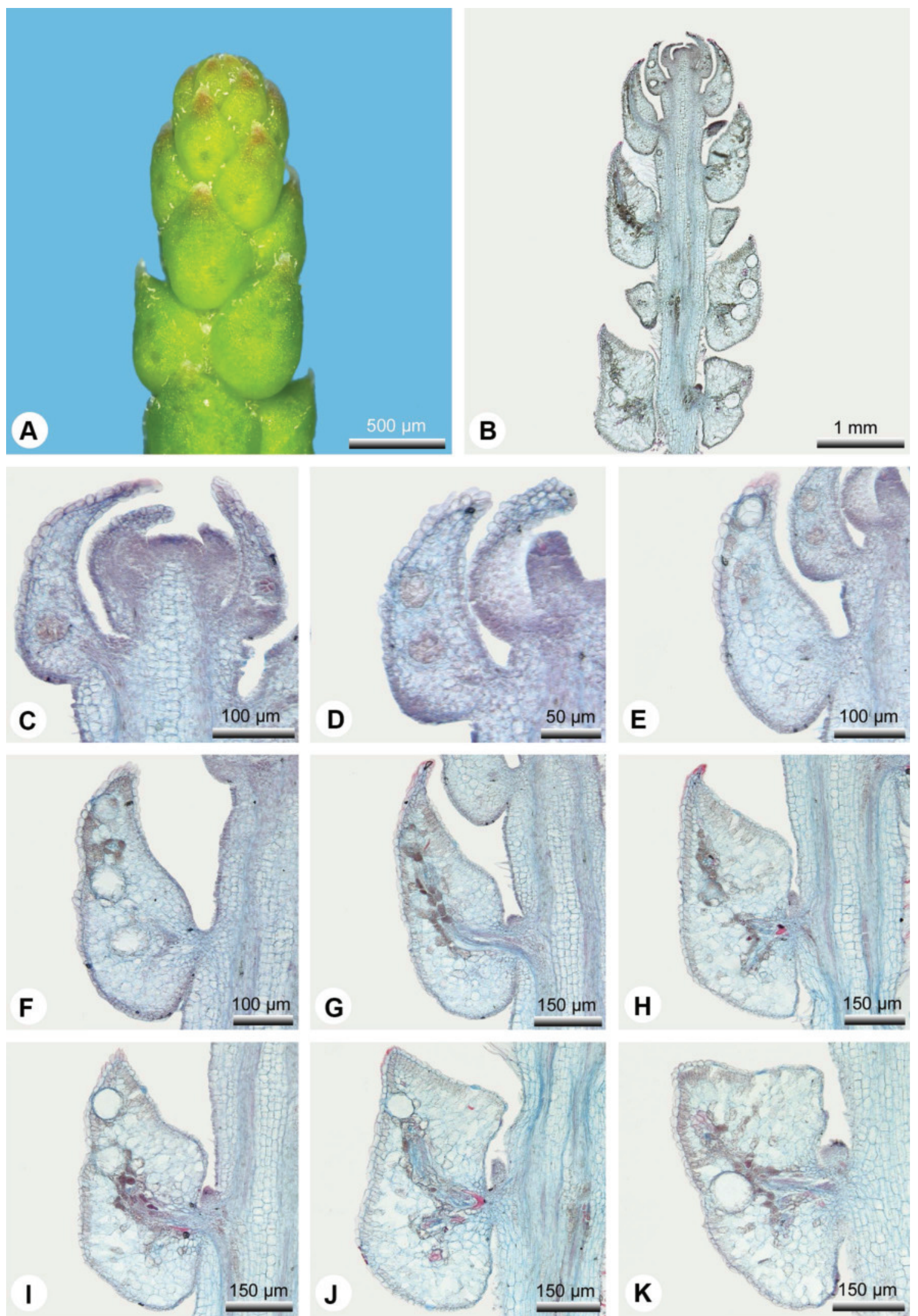

Fig. 6 Melaleuca micromera, morphogenesis of mature leaves (microtome sections); a detail of a shoot apex with young leaves; $\mathbf{b}$ cross section of the shoot axis illustrated in $\mathbf{a} ; \mathbf{c}-\mathbf{k}$ developmental

sequence of the mature leaf type (for the morphogenesis different leaves developed at a shoot axis were illustrated) 

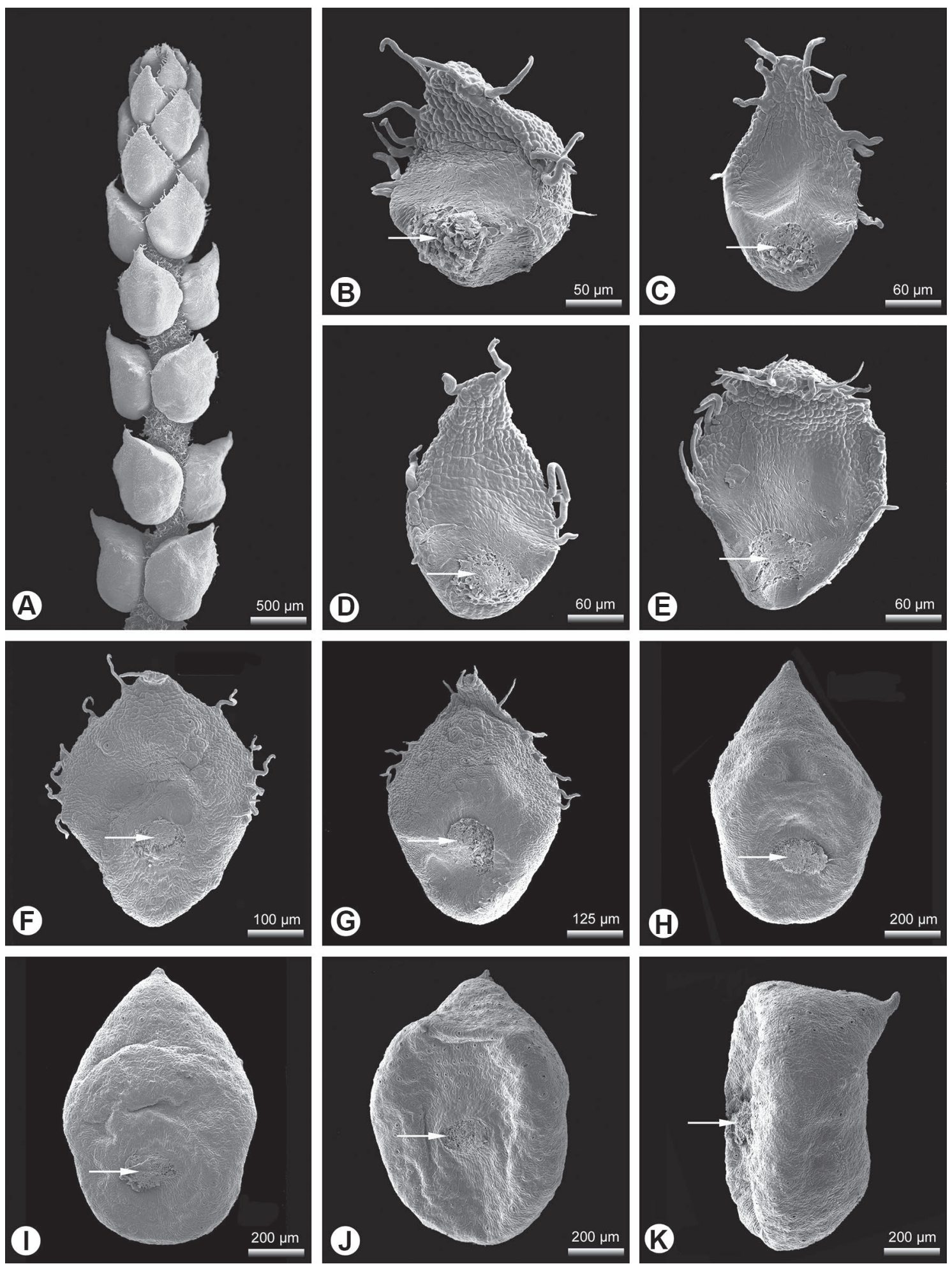

Fig.7 Melaleuca micromera, morphogenesis of mature leaves (SEM); a shoot axis; $\mathbf{b}-\mathbf{k}$ developmental sequence; in earliest ontogenetic stages the leaves are flat and bifacial, later the leaf tissues become strongly swollen so that a shield-like, flat base is formed, and the insertion point (arrow) finally occurs centrally in a truly peltate leaf. (for the morphogenesis, different leaves were taken from the shoot axis illustrated in a) 
(Asteraceae) (Hooker 1860). The leaves of O. lepidophyllus Steetz are very similar (Bentham 1866). Existing flora treatments recognize the peltate morphology of $M$. micromera leaves (Bentham 1866; Brophy et al. 2013), but without any mention of the processes producing it. Leinfellner (1953) described $M$. micromera leaves as analogous to hypopeltate leaves, but we suggest avoiding that because the term applies to the classical type of peltation; in hypopeltate leaves, the upper surface should be formed exclusively by the abaxial side, the petiole should have an unifacial structure and there are other important differences to the situation in $M$. micromera (see Troll 1932; Franck 1976; Weberling 1981; Fukushima and Hasebe 2014).

The great majority of species with the classical type of leaf peltation are herbaceous perennials from very moist, seasonally waterlogged, swampy or aquatic habitats; peltation is rare amongst woody plants (Ebel 1998). While Ebel could not provide a satisfying functional interpretation for the typically flat, bifacial, unreduced leaves on erect petioles of such species, Givnish and Vermeij (1976) suggested that these attributes lead to high lamina exposure and efficient light capture; this is possibly competitively important in dense vegetation.

In sharp contrast to this, $M$. micromera is a shrub with extreme leaf reduction from sites with regular summer water deficit and infertile soils. To what extent xeromorphy related to water deficit or scleromorphy related to nutrient deficiency are involved in this case is not clear (see Dörken and Parsons 2016, 2017; Dörken et al. 2017).

The two Melaleuca species also differ significantly in the pubescence of their shoot axis, which in M. minutifolia is glabrous throughout its entire lifespan. In M. micromera the shoot axis of juvenile individuals is also glabrous, but from the time the juvenile transitional leaves develop, the shoot axis becomes strongly pubescent and finally covered with a thick layer of short brownish trichomes.

\section{The functional transformation from juvenile to mature leaves}

In both taxa a functional transformation of the leaves takes place. In juvenile leaves (all stages up to and including the juvenile needle leaves) the morphologically adaxial side of the leaf is light-exposed and the morphologically abaxial side is shaded. Thus, palisade parenchyma is located adaxially and the majority of stomata are abaxial. In mature leaves, palisade parenchyma is still developed towards the light-exposed and spongy parenchyma towards the shaded surface, as is also the case for the stomata. However, due to the leaf reduction of mature leaves in $M$. micromera and the adpressed orientation of mature leaves in $M$. minutifolia, the morphologically abaxial side becomes light-exposed and the morphologically adaxial side shaded. Thus, the anatomical situation in mature leaves is the converse of the juvenile one with palisade parenchyma being developed towards the morphologically abaxial and the majority of stomata being located at the morphologically adaxial side of the leaf. Thus, in mature leaves the morphologically ad- and abaxial sides no longer correspond to the functional/physiological upper and lower side of the leaves as they did in the juvenile leaf types. This finding clearly shows that the functional leaf anatomy is strongly influenced by exposure to solar radiation rather than to, e.g., gravitational forces. This impact of light exposure on the leaf anatomy, particularly the distribution of palisade and spongy parenchyma and stomata, is best demonstrated in M. minutifolia. In this taxon, both juvenile and mature leaves are bifacial, because only one side of the leaf is light exposed. In juvenile leaves this is the adaxial, and in mature leaves it is the abaxial side. Only the juvenile transitional leaves are aequifacial, because resulting from their intermediate angular upright orientation, both sides of the leaves are light exposed. A similar reorientation is observable for the distribution of stomata, where the juvenile leaves are amphistomatic, but with the majority of stomata located on the shaded abaxial side, while the mature leaves are epistomatic, with stomata developed mostly at the new shaded side.

\section{Comparison to other scale leafed taxa}

Such a functional morpho-anatomical transformation is quite common among taxa showing a comparable leaf reduction when mature. In the investigated Melaleuca species, the solar radiation always influences only the single leaf unlike the complete shoot as can be observed with the plagiotropic shoot axis of several scale leaved conifers, e.g., several Cupressaceae (Imamura 1937; Fitting 1950; Napp-Zinn 1966; Dörken 2013). Within these taxa a kind of "superimposed bifaciality" is developed, which affects not just a single leaf, but the complete leafy plagiotropic lateral shoot. In this case, the light exposed leaves of the upper side of the shoot axis represent sun leaves and the shaded ones on the lower side of the shoot axis shade leaves. In scale-leaved Cupressaceae taxa showing a differentiation into median and lateral leaves such a "superimposed bifaciality" is even more complex (Dörken 2013). In this group the upper light-exposed median leaves are still sun leaves with the respective sun leaf anatomy, the lower shaded median leaves show a typical shade leaf structure. The lateral leaves have a mixed light exposure, a fact that leads to a lateral differentiation within the leaves where palisade parenchyma is located towards all light-exposed and spongy parenchyma towards all shaded parts of the lateral leaves. Due to the fact, that in the investigated Melaleuca species the lateral branches are not plagiotropic, but upright to ascending, a predominantly light-exposed shoot 
surface as described above for scale leaved Cupressaceae does not exist. In consequence, in the investigated Melaleuca species the anatomical dorsiventrality exclusively affects a single leaf. By a complete reorientation of the palisade parenchyma towards the new light-exposed, and stomata towards the new shaded side, the morphologically abaxial side becomes functionally and physiologically adaxial and the morphologically adaxial side functionally and physiologically abaxial.

\section{Concluding discussion}

Studies on the foliar change in $M$. minutifolia and $M$. micromera show strong size reductions in the mature leaf type of both taxa. However, between the species, the pathway of leaf reduction differs significantly, producing an inverse bifacial, linear structure in M. minutifolia while in M. micomeria the mature leaves are no longer bifacial, linear structures as in the case of the juvenile leaves types, but become strongly reduced aequifacial, minute peltate leaves. The ontogenetic studies on peltation in $M$. micromera show that it is characterized by a strong swelling of the mesophyll, which finally leads to a shield-like leaf base. A fusion of the leaf margin forming a meristematic cross zone above the petiole as is frequently described for peltation in the classical sense is always lacking in $M$. micromera. This and other data clearly indicate that as well as the classical type of peltation, a novel, second strategy for achieving peltation needs to be distinguished.

Author contribution statement VD and RP constructed and designed the experiments. VD performed the experiments and made the figures. Both authors analyzed the data and wrote the paper.

Acknowledgements We are grateful to Mrs. Anne Kern and Mr. Otmar Ficht (Botanic Garden, University of Konstanz, Germany) for producing the seedlings. Furthermore, we thank Dr. Michael Laumann and Dr. Paavo Bergmann (Electron Microscopy Center, Department of Biology, University of Konstanz, Germany) for technical support (paraffin technique).

\section{Compliance with ethical standards}

Conflict of interest The authors declare that they have no conflict of interest.

\section{References}

Atlas of Living Australia (2017) Atlas of Living Australia. http://www. ala.org.au. Accessed 7 May 2017
Australia's Virtual Herbarium (2017) Australia's Virtual Herbarium. https://avh.chah.org.au. Accessed 10 May 2017

Baker RT, Smith HG (1910) A research on the pines of Australia. Technological Museum, Technical Education Series No. 16. Government Printer, Sydney

Barnes ME (2014) Ernst Haeckel's biogenetic law (1866). In: The embryo project encyclopedia. Arizona State University, Tempe, pp 1-5

Beadle NCW (1966) Soil phosphate and its role in molding segments of the Australian flora and vegetation with special reference to xeromorphy and sclerophylly. Ecology 47:992-1007

Beck CB (2010) An introduction to plant structure and development, 2nd edn. Cambridge University Press, Cambridge

Bentham G (1866) Flora Australiensis, vol 3. Lowell Reeve, London

Biffin E, Brodribb TJ, Hill RS, Thomas P, Lowe A (2012) Leaf evolution in Southern Hemisphere conifers tracks the angiosperm ecological radiation. Proc R Soc Lond Ser B Biol Sci 279:341-348

Blum A (1996) Crop responses to drought and the interpretation of adaptation. Pl Growth Regul 20:135-148

Blum A, Arkin GF (1984) Sorghum root growth and water use as affected by water supply and growth duration. Field Crop Res 9:131-142

Bosabalidis AM, Kofidis G (2002) Comparative effects of drought stress on leaf anatomy of two olive cultivars. Pl Sci 163:375-379

Bresinsky A, Körner C, Kadereit JW, Neuhaus G, Sonnewald U (2008) Strasburger, Lehrbuch der Botanik, 36th edn. Spektrum, Heidelberg

Brodribb TJ, Hill RS (1998) The photosynthetic drought physiology of a diverse group of southern hemisphere conifer species is correlated with minimum seasonal rainfall. Funct Ecol 12:465-471

Brophy JJ, Craven LA, Doran JC (2013) Melaleucas, their botany, essential oils and uses. ACIAR, Canberra

Cambage RH (1914) Dimorphic foliage of Acacia rubida and fructification during bipinnate stage. J Proc R Soc New S Wales 48:136-140

Coulter JM, Chamberlain CJ (1928) Morphology of gymnosperms, 4th edn. University of Chicago Press, Chicago

De Laubenfels DJ (1953) The external morphology of coniferous leaves. Phytomorphology 3:1-20

Dörken VM (2013) Leaf dimorphism in Thuja plicata and Platycladus orientalis (thujoid Cupressaceae s. str., Coniferales): the changes in morphology and anatomy from juvenile needle leaves to mature scale leaves. Pl Syst Evol 299:1991-2001

Dörken VM, Jagel A (2014) Pinus sylvestris-Wald-Kiefer (Pinaceae), Baum des Jahres 2007. Jahrb Bochumer Bot Ver 5:246-254

Dörken VM, Parsons RF (2016) Morpho-anatomical studies on the change in the foliage of two imbricate-leaved New Zealand podocarps: Dacrycarpus dacrydioides and Dacrydium cupressinum. Pl Syst Evol 302:41-54

Dörken VM, Parsons RF (2017) Morpho-anatomical studies on the leaf reduction in Casuarina (Casuarinaceae): the ecology of xeromorphy. Trees 31:1165-1177

Dörken VM, Parsons RF, Marshall AT (2017) Studies on the foliage of Myricaria germanica (Tamaricaceae) and their evolutionary and ecological implication. Trees 31:997-1013

Düll R, Kutzelnigg H (2011) Taschenlexikon der Pflanzen Deutschlands und angrenzender Länder, 7th edn. Quelle and Meyer, Wiebelsheim

Ebel F (1998) Die Schildblättrigkeit krautiger Angiospermen-Sippen in ihrer Beziehung zu Standort und Verbreitung. Flora 193:203-224

Eckenwalder JE (2009) Conifers of the World. Timber Press, Portland

Fitting H (1950) Weitere Beobachtungen über die Induktion der Dorsiventralität in den blattartigen Zweigsystemen von Cupressaceen. Planta 37:676-696

FloraBase (2017) The Western Australian Flora. https://florabase.dpaw. wa.gov.au. Accessed 24 May 2017 
Foster AS, Gifford EM (1974) Comparative morphology of vascular plants, 2nd edn. Freeman, San Francisco

Franck DH (1976) The morphological interpretation of epiascidiate leaves: an historical perspective. Bot Rev 42(3):345-388

Fukushima K, Hasebe M (2014) Adaxial-abaxial polarity: the developmental basis of leaf shape diversity. Genesis 52:1-18

Gerlach D (1984) Botanische Mikrotomtechnik, eine Einführung, 2nd edn. Thieme, Stuttgart

Givnish TJ, Vermeij GJ (1976) Size and shapes of liane leaves. Am Nat 110:743-778

Gleissberg S, Groot EP, Schmalz M, Eichert M, Kölsch A, Hutter S (2005) Developmental events leading to peltate leaf structure in Tropaeolum majus (Tropaeolaceae) are associated with expression domain changes of a YABBY gene. Dev Genes Evol 215:313-319

Hagemann W, Gleissberg S (1996) Organogenetic capacity of leaves: the significance of marginal blastozones in angiosperms. Pl Syst Evol 199:121-152

Hill RS (1998) Fossil evidence for the onset of xeromorphy and scleromorphy in Australian Proteaceae. Aust Syst Bot 11:391-400

Hill RS, Merrifield HE (1993) An Early Tertiary macroflora from West Dale, southwestern Australia. Alcheringa 17:285-326

Hooker JD (1860) The botany of the Antarctic voyage of H.M. discovery ships 'Erebus' and 'Terror', vol 3. Flora Tasmaniae. Reeve, London

Howchin W (1930) The building of Australia and the succession of life. part III. Pleistocene and Recent. Harrison Weir, Government Printer, Adelaide

Imamura SL (1937)) Über die aitiogene Dorsiventralität der Assimilationsorgane bei höheren Pflanzen. Bot Mag (Tokyo) 61:308-316

Jurzitza G (1987) Anatomie der Samenpflanzen. Thieme, Stuttgart

Keng H (1963) Aspects of the morphology of Phyllocladus hypophyllus. Ann Bot (Oxford) 27:69-80

Keng H (1974) The Phylloclade of Phyllocladus and its possible bearing on the branch systems of progymnosperms. Ann Bot (Oxford) 38:757-764

Keng H (1979) A monograph of the genus Phyllocladus (Coniferae). Natural Publishing Company, Taipei

Korner C (2003) Alpine plant life, 2nd edn. Springer, Berlin

Kück U, Wolf G (2009) Botanisches Grundpraktikum, 2nd edn. Springer, Berlin

Langner W (1963) Die Entstehung sogenannter Jugendformen bei Chamaecyparis. Silvae Genet 13:57-63

Leinfellner W (1953) Die "schildförmigen" Laubblätter von Melaleuca micromera Schau. Österr Bot Z 100:639-645

Leins P, Erbar C (2008) Blüte und Frucht: Morphologie, Entwicklungsgeschichte, Phylogenie, Funktion, Ökologie, 2nd edn. Schweizerbart'sche Verlagsbuch-handlung, Stuttgart

Leins P, Erbar C (2010) Flower and fruit: morphology, ontogeny, phylogeny, function and evolution. Schweizerbart'sche Verlagsbuchhandlung, Stuttgart

Little DP (2006) Evolution and circumscription of the True Cypresses (Cupressaceae: Cupressus). Syst Bot 31(3):461-480
Loveless AR (1961) A nutritional interpretation of sclerophylly based on differences in the chemical composition of sclerophyllous and mesophytic leaves. Ann Bot (Oxford) 25:168-184

Loveless AR (1962) Further evidence to support a nutritional interpretation of sclerophylly. Ann Bot (Oxford) 26:551-561

McMillan C (1956) The edaphic restriction of Cupressus and Pinus in the coast ranges of central California. Ecol Monogr 26:178-212

Napp-Zinn K (1966) Anatomie des Blattes. I. Blattanatomie der Gymnospermen. Bornträger, Berlin

Natho G, Müller C, Schmidt H (1990) Morphologie und Systematik der Pflanzen, Teil 2 (L-Z). UTB Gustav Fischer Verlag, Stuttgart

Parsons RF (2010) Whipcord plants: a comparison of south-eastern Australia with New Zealand. Cunninghamia 11:277-281

Pedley L (1986) Derivation and dispersal of Acacia (Leguminosae), with particular reference to Australia and the recognition of Senegalia and Racosperma. Bot J Linn Soc 92:219-254

Rudall RJ (2007) Anatomy of flowering plants, an introduction to structure and development. Cambridge University Press, Cambridge

Salleo S, Nardini A (2000) Sclerophylly: evolutionary advantage or mere epiphenomenon? Plant Biosystems 134:247-259

Schütt P (2004) Thuja occidentalis Linné 1753, Abendländischer Lebensbaum. In: Schütt P, Weisgerber H, Schuck HJ, Lang UM, Stimm B, Roloff A (eds) Lexikon der Nadelbäume. Nicol, Hamburg, pp 591-598

Seddon G (1974) Xerophytes, xeromorphs and sclerophylls: the history of some concepts in ecology. Biol J Linn Soc 6:65-87

Seidling W, Ziche D, Beck W (2012) Climate responses and interrelations of stem increment and crown transparency in Norway Spruce, Scots Pine and Common Beech. For Ecol Manag 284:196-204

Sharp BR, Bowman DMJS (2004) Net woody vegetation increase confined to seasonally inundated lowlands in an Australian tropical savanna, Victoria River District, Northern Territory. Aust Ecol 29:667-683

Stebbins GL (1950) Variation and evolution in plants. Columbia University Press, New York

Taiz L, Zeiger E, Møller IM, Murphy A (2014) Plant physiology and development, 6th edn. Oxford University Press, Oxford

Tetzlaf M (2005) Die Anatomie des Gymnospermenblattes unter funktionellen und evolutiven Gesichtspunkten—diploma, RuhrUniversity, Bochum

Thoday D (1931) The significance of reduction in the size of leaves. J Ecol 19:297-303

Throm G (2007) Grundlagen der Botanik, $2^{\text {nd }}$ edn. Nikol, Hamburg

Troll W (1932) Morphologie der schildförmigen Blätter. Planta $17: 153-314$

Wagenitz G (2008) Wörterbuch der Botanik, 2nd edn. Nikol, Hamburg

Weberling F (1981) Morphologie der Blüten und Blütenstände. Ulmer, Stuttgart

Weiler E, Nover L (2008) Allgemeine und molekulare Botanik. Thieme, Stuttgart 